\title{
POLYMORPHIC VARIATIONS IN VDR GENE IN SAUDI WOMEN WITH AND WITHOUT POLYCYSTIC OVARY SYNDROME (PCOS) AND SIGNIFICANT INFLUENCE OF SEVEN POLYMORPHIC SITES ON ANTHROPOMETRIC AND HORMONAL PARAMETERS
}

\author{
POLIMORFNE VARIJACIJE VDR GENA KOD SAUDIJSKIH ŽENA SA I BEZ SINDROMA \\ POLICISTIČNIH OVARIJUMA (PCOS) I ZNAČAJ UTICAJA SEDAM POLIMORFNIH MESTA \\ NA ANTROPOMETRIJSKE I HORMONSKE PARAMETRE
}

\author{
Arwa Al Thomali14, Maha H. Daghestani ${ }^{1,4}$, Mazin H. Daghestani ${ }^{3}$, Namik Kaya $^{2}$, Arjumand Warsy ${ }^{4}$ \\ ${ }^{1}$ Department of Zoology, College of Science, King Saud University, Saudi Arabia \\ ${ }^{2}$ Department of Genetics, King Faisal Specialist Hospital and Research Centre, Riyadh, Saudi Arabia \\ ${ }^{3}$ Department of Obstetrics and Gynecology, Umm-Al-Qura University, Makkah, Saudi Arabia \\ ${ }^{4}$ Central Laboratory, Center for Science and Medical Studies for Girls, King Saud University, Saudi Arabia
}

\begin{abstract}
Summary
Background: This study was designed to evaluate the associations between vitamin D receptor (VDR) gene polymorphisms and biochemical characteristics of Saudi women with polycystic ovary syndrome (PCOS).

Methods: Serum levels of LH, FSH, and Vitamin D were measured in 33 women: 16 patients and 17 normal controls (18 to 36 years). DNA was extracted and used for sequencing of the exons of VDR gene using $A B I$ PRISM 3730xi Genetic Analyzer.

Results: Weight, BMI, Vit D, LH and FSH levels were higher in the PCOS patients compared to control group, where Vit $D$ level correlated positively and significantly with $\mathrm{FSH}$, in the control, but showed a negative and non-significant correlation in the PCOS patients. Sequencing results showed extensive polymorphisms in both groups, but the differences in the frequencies were not significant. Demographic and hormonal parameters were compared in the different genotypes of the SNPs. Significant differences were observed in the values of the studied parameters in rs11168276,
\end{abstract}

Address for correspondence:

Dr. Maha Daghestani

Department of Zoology,

College of Sciences, King Saud University, Riyadh,

11495, Kingdom of Saudi Arabia

Tel: +966-1-464-7272 ×39612, +966-1-442-4585

e-mail: mdaghestani@ksu.edu.sa

\section{Kratak sadržaj}

Uvod: Ovo izučavanje je planirano da proceni vezu između genskog polimorfizma vitamin D receptora (VDR) i biohemijskih karakteristika saudijskih žena sa sindromom policističnih ovarijuma (PCOS).

Metode: Nivoi serumskog LH, FSH i vitamina D mereni su kod 33 žene: 16 pacijenata i 17 zdravih žena (između $18 \mathrm{i}$ 36 godina). DNK je izolovan i korišćen za sekvenciranje eksona VDR gena primenom AQBI PRISM 3730xi Genetic Analyser-a.

Rezultati: Težina, BMI, nivoi vitamina $D$, LH i FSH bili su viši kod pacijenata sa PCOS nego kod kontrolne grupe, dok su nivoi vitamina $D$ pozitivno i značajno korelirali sa FSH kod kontrolne grupe, dok je nađena negativna korelacija kod pacijenata sa PCOS. Rezultati sekvenciranja su pokazali ekstenzivni polimorfizam u obe grupe, a razlike u frekvencama u obe grupe nisu bile značajne. Demografski i hormonski parametri su poređeni kod različitih genotipova SNPs. Značajne razlike su nađene kod vrednosti proučavanih parametara u rs11168276, rs2228570, rs11168266,

List of abbreviations: BMI, Body mass index; $\mathrm{Cl}, 2.5-95 \%$ confidence interval; ELISA, Enzyme Linked Immuno Sorbent Assay; FSH, Follicle stimulating hormone; GnRH, Gonadotropin-releasing hormone; LH, Luteinizing hormone; IRB, Institutional Review Board; N, Number; OR, Odds ratio; PCOS, Polycystic ovary syndrome; PCR, Polymerase Chain Reaction; P, P value-Statistical significance; r, Correlation coefficient; s, Second; SNP, Single nucleotide polymorphisms; UTR, Untranslated region; Vit D, Vitamin D; VDR, Vitamin D receptor; VDR, Vitamin $D$ receptor gene; $\chi^{2}$, Chi-square 
rs2228570, rs11168266, rs3858733, rs121909790, rs11168265 and rs731236. Vitamin D level was influenced significantly by the genotypes of rs11168265 (AA) $(p=0.008)$, rs11168276 (AA; $p=0.018)$ and $r s 731236$ (CC; $\mathrm{p}=0.024)$.

Conclusion: Vitamin D deficiency does not associate with PCOS in Saudi females. Several SNPs are identified in the VDR gene, in normal and PCOS females, but there is no difference in their frequencies between the two groups. The results show that polymorphism in VDR gene influences certain anthropometric and hormonal parameters in PCOS patients. Further detailed studies are required to confirm the associations between VDR and PCOS.

Keywords: vitamin D receptor; polycystic ovarian syndrome, SNPs, vitamin D

\section{Introduction}

Vitamin $D($ Vit $D)$ is involved in a broad variety of biological processes (1) and plays a major role in many hormonal and metabolic disorders associated with the female reproductive system, such as Polycystic Ovary Syndrome (PCOS) (2). Most of the processes brought about by Vit $D$ are mediated through its binding to the Vit D receptor (VDR) (3). The VDR is a member of the nuclear receptor superfamily and is spread across different tissues, including intestine, kidney, parathyroid gland, pancreatic beta calls, and bones, all involved in maintenance of calcium homeostasis. It is also expressed in human ovarian tissue and in the human endometrium (4-5), and is shown to have a role in steroidogenesis of sex hormones (6). Recently, considerable interest has focused on the pathogenesis of PCOS, since it is one of the most common endocrine disorders in women of childbearing age and has a strong genetic predisposition (7). Some studies have implicated an involvement of mutant VDR gene in the pathogenesis of PCOS. Other studies have shown an association between PCOS and $V$ it $D$ deficiency and insulin resistance (8-11). A higher prevalence of $V$ it $D$ deficiency has been reported in women with PCOS $(12,13)$ and since the physiological effect of $V$ it $D$ is dependent on the VDR, several investigations have been directed to study the genetic mutations and polymorphisms in VDR in PCOS patients (14-17).

The VDR Gene is located on chromosome 12 q13.11 and spans about 75kb with 11 exons. Many allelic variants due to single nucleotide polymorphisms (SNP) have been reported in the VDR gene and differences are obvious in different racial groups (1,18-20). Wehr and coworkers (21) reported no significant influence of genetic variations and PCOS susceptibility, but VDR and Vit D level-related variants were shown to be associated with some dis- rs3858733, rs121909790, rs11168265, i rs731236. Na vitamin $D$ značajno su uticali genotipovi rs11168265 $(A A)(p=0,008)$, rs11168276 (AA; $p=0,018)$ i rs731236 $(C C ; p=0,024)$.

Zaključak: Deficit vitamina D nije povezan sa PCOS kod saudijskih žena. Nekoliko SNPs je identifikovano kod VDR gena kako kod zdravih žena tako i onih sa PCOS, i nije bilo razlike u njihovim frekvencijama u obe grupe. Rezultati su pokazali da polimorfizam VDR gena utiče na izvesne antropometrijske i hormonske parametre u PCOS pacijenata. Neophodna su dalja izučavanja kako bi se potvrdile veze između VDR i PCOS.

Ključne reči: receptor vitamina $D$, sindrom policističnih ovarijuma, SNPs, vitamin D

orders in PCOS including Vit D levels. Mahmoudi and coworkers (22) reported that the Apal (rs7975232) genotype "AA« could be considered as a marker of decreased susceptibility for PCOS, while the "aa" genotype was associated with an increased risk for PCOS. Mcgrath et al. (23) showed that there was a significant relationship between rs 10735810 (merged with rs2228570) and levels of Vit D, and the $T$ allele was associated with higher concentrations of Vit D. In contrast, Bagheri et al. (24) reported no statistically significant association with PCOS susceptibility. Wehr et al. (21), found that Apal (rs7975232) variants are associated with testosterone levels in PCOS patients. A study from Iran reported an association between VDR Taql (rs731236) (CC) genotype, and serum levels of LH (25). This finding was confirmed by Bagheri and coworkers (26).

Since there are several contradictory reports of association between SNPs in VDR and PCOS and associated hormonal abnormalities, we designed this study to investigate the levels of Vit $D$ and polymorphism in VDR gene in Saudi females with and without PCOS and to correlate the findings to demographic and hormonal values in the two groups.

\section{Materials and Methods}

\section{Study population}

The study was approved by the Institutional Ethical Committee, and an IRB was obtained. Each female who volunteered to join in the study, was explained the nature of the study and a signed informed consent was obtained. The study group included 33 women with age ranging from 18-36 years (16 women suffering from PCOS and 17 healthy women as normal controls). The PCOS patients were attending clinics at the An Noor Hospital in Makkah Al Mukarama and were diag- 
Table I Primers used for amplification of different fragments of the VDR Gene.

\begin{tabular}{|c|c|c|c|c|}
\hline Exone & $\begin{array}{c}\text { Forward Primer }(F) \\
\text { or Reverse Primer }(R)\end{array}$ & Sequence & MT & $\begin{array}{l}\text { Annealing } \\
\text { Temp. }\left({ }^{\circ} \mathrm{C}\right)\end{array}$ \\
\hline \multirow{2}{*}{1} & $\mathrm{~F}$ & GTGGCCTATAGGGTGGTTGA & 79 & \multirow{2}{*}{54} \\
\hline & $\mathrm{R}$ & CATACCTGGGCCCTGTAAGA & 79 & \\
\hline \multirow{2}{*}{2} & $\mathrm{~F}$ & TGTGCTGATTGTCCCATTG & 77 & \multirow{2}{*}{60} \\
\hline & $\mathrm{R}$ & CAGTGGTTACAGGCTGACTCTG & 80 & \\
\hline \multirow{2}{*}{3} & $\mathrm{~F}$ & СTTCCCACTGCTCCTGCTAC & 80 & \multirow{2}{*}{60} \\
\hline & $\mathrm{R}$ & ATCCTGGGTGGTATCCCTTC & 79 & \\
\hline \multirow{2}{*}{4} & $\mathrm{~F}$ & CTGAGCTCCCTGGTGGTG & 79 & \multirow{2}{*}{60} \\
\hline & $\mathrm{R}$ & GGAGCTGAGAGGAGGGAAAA & 80 & \\
\hline \multirow{2}{*}{5} & $\mathrm{~F}$ & GGCCTCATGTCTTCTGTTGG & 79 & \multirow{2}{*}{60} \\
\hline & $\mathrm{R}$ & GCTGGCAGCTACAGAGGAAG & 80 & \\
\hline \multirow{2}{*}{6} & $\mathrm{~F}$ & CGAGTGTTAAAGCCCCTCCT & 81 & \multirow{2}{*}{58} \\
\hline & $\mathrm{R}$ & CTGCССТСТGTСССТАСТСС & 79 & \\
\hline \multirow{2}{*}{7} & $\mathrm{~F}$ & TGAACAGAACTGGGGTAGGG & 79 & \multirow{2}{*}{54} \\
\hline & $\mathrm{R}$ & TTGGGTAAGTCACCCCTTTC & 78 & \\
\hline \multirow{2}{*}{8} & $\mathrm{~F}$ & GAAGGGTGACCTGTGGAGTC & 79 & \multirow{2}{*}{54} \\
\hline & $\mathrm{R}$ & AGGTTGCAGTGAGCCGAGAT & 78 & \\
\hline \multirow{2}{*}{9} & $\mathrm{~F}$ & AGGAACACTCTTGTCCCTTCC & 79 & \multirow{2}{*}{54} \\
\hline & $\mathrm{R}$ & TCCCTGTTGGTGCCTAACTC & 79 & \\
\hline \multirow{2}{*}{10} & $\mathrm{~F}$ & TCTTTTTCAGCTCCCAGATTC & 77 & \multirow{2}{*}{60} \\
\hline & $\mathrm{R}$ & GCTCTGCAAACCAGCAAAGT & 78 & \\
\hline \multirow{2}{*}{11} & $\mathrm{~F}$ & TGGTATCACCGGTCAGCAGT & 80 & \multirow{2}{*}{58} \\
\hline & $\mathrm{R}$ & GTGAGGAGGGCTGCTGAGTA & 79 & \\
\hline \multirow{2}{*}{ UTR } & $\mathrm{F}$ & CGAAGTGTTTGGCAATGAGA & 77 & \multirow{2}{*}{54} \\
\hline & $\mathrm{R}$ & GAGAGGGAGACCCCACTAGG & 81 & \\
\hline \multirow{2}{*}{ UTR } & $\mathrm{F}$ & GGACAGAGACACCTGCACCT & 80 & \multirow{2}{*}{56} \\
\hline & $\mathrm{R}$ & AGGGCTTCCACCTCAACC & 79 & \\
\hline ITD & $\mathrm{F}$ & GTCCCTGTCACCAAGCTCAC & 80 & \\
\hline UTR & $\mathrm{R}$ & CTCTTAGCCCTGTGGGTGAA & 79 & 56 \\
\hline PTD & $\mathrm{F}$ & GGGTCTGGAGAAGCAGTGAG & 77 & 60 \\
\hline UIR & $\mathrm{R}$ & CATTCCCCAAACTCAAGCA & 80 & 60 \\
\hline ITD & $\mathrm{F}$ & AGAAAGGCGTTCTTCGAGGT & 78 & \\
\hline UIR & $\mathrm{R}$ & TCAAACAAGGGTCTCTCCCTA & 78 & 60 \\
\hline ITD & $\mathrm{F}$ & GGGGAGAACTTACATTGTGAAA & 77 & 60 \\
\hline UIR & $\mathrm{R}$ & CGATCTCAGCTCACTGCAAC & 79 & bu \\
\hline ITP & $\mathrm{F}$ & AGGCTGAGGCAGAAGAATTG & 78 & \\
\hline UIR & $\mathrm{R}$ & TGAGGCAACAGCATTATCCA & 77 & 60 \\
\hline ITP & $\mathrm{F}$ & CCAACCCATCAGAAGGAGAA & 78 & 60 \\
\hline UIR & $\mathrm{R}$ & TTCCAGTTAGCCAGCCAGAG & 79 & bU \\
\hline ITP & $\mathrm{F}$ & GAGAAGGTGCCCCAAAATG & 78 & \\
\hline UIR & $\mathrm{R}$ & AATGATTCATCTCCCATAAGGTC & 77 & 60 \\
\hline
\end{tabular}


nosed using the Rotterdam criteria (27). A women was diagnosed as PCOS if she had at least 2 of the following criteria [menstrual abnormalities either amenorrhea (absence of periods for more than 6 months) or oligomenorrhea (fewer than six menstrual periods in the preceding year) and the appearance of oversized ovaries with the presence of more than 12 ovarian follicles by ultrasound scanning (21). In addition, all 16 women with PCOS were Saudis and were genetically unrelated. The controls were normal healthy females with regular menstrual cycle and no indications of sign and symptoms of PCOS or any other gynecological problem. History was taken and standard anthropometric data [height $(\mathrm{cm})$, weight $(\mathrm{Kg})$ and body mass index $(\mathrm{BMI})\left(\mathrm{kg} / \mathrm{m}^{2}\right)$ ] were obtained from each patient and control.

\section{Sample collection}

Fasting blood samples $(10 \mathrm{~mL})$ were collected by venipuncture in tubes with no anti-coagulant, for analyses of the hormones, and in EDTA tubes for DNA extraction. The samples were immediately centrifuged to obtain the serum which was stored at $-20{ }^{\circ} \mathrm{C}$ until required for analysis.

\section{Biochemical analysis}

The serum was used for the analysis of luteinizing hormone (LH), follicle stimulating hormone (FSH) and Vit D. The measurements of $\mathrm{LH}$ and FSH were made using Enzyme Linked Immuno Sorbent Assay (ELISA) from (Phoenix Pharmaceuticals, Inc., Belmont, CA, USA) and the Vit D level was assayed by ELISA, using kits from EagleBio (Inc, Nashua).

\section{DNA extraction}

Genomic DNA was extracted from blood using DNA Extraction kits (QIAGEN) (Catalog Number: 158359), for each PCOS patient and the control sample.

\section{DNA sequencing of the VDR gene}

The VDR gene was divided into the exons. Primers were designed for each fragment using PRIMER 3 program. Each exon and the UTR fragments were amplified by the Polymerase Chain Reaction (PCR) using the primers presented in Table I on the Applied Biosystems thermocycler. The PCR cycles consisted of three major steps of PCR, which were repeated for 35 cycles. Denaturation at $94{ }^{\circ} \mathrm{C}$ for $40 \mathrm{~s}$; annealing at $54{ }^{\circ} \mathrm{C} 40 \mathrm{~s}$, and extension step at $72{ }^{\circ} \mathrm{C}$ for $40 \mathrm{~s}$. The PCR products were separated on $1.8 \%$ agarose gels to access the purity, and bands were visualized using ethidium bromide for imagining under ultraviolet light by gel documentation instrument. Each, clean PCR product obtained by amplification of the patients and control samples, was subjected to DNA sequencing. Sequencing of the VDR was carried out using Sanger Sequencing at the Core facility at King Faisal Specialist Hospital and Research Center using ABI PRISM 3730xi Genetic Analyzer (Cat\#3730S, Applied Biosystems, Foster city, CA 94404, USA). The resulting sequence was matched with the reference sequence, and genotypes were constructed for each patient and control.

\section{Statistical analyses}

All data were analyzed using SAS (version 9.3). Data are presented as mean \pm SD or as percentages. Correlation studies were conducted, and Pearson Correlation coefficient $(r)$ and $p$ values were obtained. The genotypes were obtained manually, by comparison, using DNAstar and the genotype and allele frequencies were calculated separately for the PCOS and control group. The patients and control data were compared, and odds ratio (OR), 2.5-95\% confidence interval $(\mathrm{Cl})$, chi-square $\left(\chi^{2}\right)$ and the $\mathrm{p}$ values were obtained. Allele frequencies were calculated and compared. Statistical significance was defined as $\mathrm{p}<0.05$.

\section{Results}

Table II presents the demographic data and hormone values obtained in the patients and control groups and the results of the Student's t test to show the significance of the difference between the two groups. Weight, Vit D and LH were higher in the PCOS patients, but age and BMI did not differ significantly. The Vit D level showed a positively skewed distribution in both groups. In the control group the minimum and maximum values ranged from 25.0-56.0 $\mathrm{ng} / \mathrm{mL}(41.5 \pm 7.5 \mathrm{ng} / \mathrm{mL})$, while in the PCOS they were $30.0-60.0 \mathrm{ng} / \mathrm{mL}(47.2 \pm 6.9 \mathrm{ng} / \mathrm{mL})$ and the difference was statistically significant $(p=0.0324)$. The number of women with different levels of Vit $D$ deficiency was calculated in the two groups, and the results are presented in Table III. None of the women had severe Vit $D$ deficiency or highly elevated Vit $D$ level. Majority had optimal Vit $D$ level in both groups, but $25 \%$ of the PCOS had Vit D level in the upper normal range.

The level of Vit $D$ was correlated with the demographic data and the hormones. The correlation coefficient $(r)$, and the significance $(p)$ are presented in Table IV. Both negative and positive correlations were observed but the only significant correlation was between Vit D and FSH.

A statistically significant positive correlation was seen between the level of Vit D and FSH in the con- 
Table II Levels of demographic variables and hormonal parameters in PCOS compared to the values in the normal healthy controls.

\begin{tabular}{|l|c|c|c|}
\hline Variable & $\begin{array}{c}\text { Control } \\
(\mathrm{N}=17) \\
\text { Mean } \pm \text { SD }\end{array}$ & $\begin{array}{c}\text { PCOS } \\
(\mathrm{N}=16) \\
\text { Mean } \pm \text { SD }\end{array}$ & P value \\
\hline Weight $(\mathrm{kg})$ & $58.8 \pm 12.1$ & $71.8 \pm 11.4$ & 0.0034 * \\
\hline Height (cm) & $162.2 \pm 4.1$ & $155.2 \pm 8.6$ & 0.0078 * \\
\hline $\mathrm{BMI}\left(\mathrm{kg} / \mathrm{m}^{2}\right)$ & $35.0 \pm 9.1$ & $30.0 \pm 5.7$ & 0.0737 \\
\hline $\begin{array}{l}\text { Vit D Level } \\
(\mathrm{ng} / \mathrm{mL})\end{array}$ & $41.5 \pm 7.5$ & $47.2 \pm 6.9$ & 0.0324 * \\
\hline $\mathrm{LH}(\mathrm{IU} / \mathrm{L})$ & $8.6 \pm 1.3$ & $15.2 \pm 2.3$ & $<.0001$ * \\
\hline FSH (IU/L) & $5.8 \pm 1.4$ & $6.2 \pm 4.3$ & 0.7127 \\
\hline
\end{tabular}

$\mathrm{N}=$ Total sample; $\mathrm{SD}=$ Standard deviation; $\left({ }^{*}\right)=\mathrm{P}$-value less than 0.05

Table III LVit D Level in PCOS and control.

\begin{tabular}{|l|c|c|}
\hline \multirow{2}{*}{ Vit D level } & $\begin{array}{c}\text { Control } \\
(\mathrm{N}=17)\end{array}$ & $\begin{array}{c}\text { PCOS } \\
(\mathrm{N}=16)\end{array}$ \\
\cline { 2 - 3 } & $\mathrm{n}(\%)$ & $\mathrm{n}(\%)$ \\
\hline $\begin{array}{l}\text { Suboptimal Vit D provision } \\
(20-30 \mathrm{ng} / \mathrm{mL})\end{array}$ & $1(5.8)$ & $-(-)$ \\
\hline $\begin{array}{l}\text { Optimal Vit D level } \\
(30-50 \mathrm{ng} / \mathrm{mL})\end{array}$ & $14(82.3)$ & $12(75)$ \\
\hline $\begin{array}{l}\text { Upper } \mathrm{normal} \\
(50-70 \mathrm{ng} / \mathrm{mL})\end{array}$ & $2(11.7)$ & $4(25)$ \\
\hline Total & $17(100)$ & $16(100)$ \\
\hline
\end{tabular}

$\mathrm{N}=$ Total sample, $\mathrm{n}=$ Frequency

Table IV The Correlation between Vit D Level and the studied variables.

\begin{tabular}{|l|c|c|c|c|}
\hline \multirow{2}{*}{$\begin{array}{l}\text { Correlation } \\
\text { between Vit. } \\
\text { D and: }\end{array}$} & \multicolumn{2}{|c|}{ Control $(\mathrm{N}=17)$} & \multicolumn{2}{c|}{ PCOS $(\mathrm{N}=16)$} \\
\cline { 2 - 5 } & $\mathrm{R}$ & $\mathrm{P}$ value & $\mathrm{R}$ & P value \\
\hline Age (year) & -0.226 & 0.382 & 0.417 & 0.107 \\
\hline Weight $(\mathrm{kg})$ & 0.078 & 0.767 & -0.351 & 0.182 \\
\hline Height $(\mathrm{cm})$ & -0.258 & 0.318 & -0.255 & 0.340 \\
\hline $\mathrm{BMI}\left(\mathrm{kg} / \mathrm{m}^{2}\right)$ & 0.161 & 0.536 & -0.123 & 0.649 \\
\hline LH $(\mathrm{IU} / \mathrm{L})$ & 0.090 & 0.731 & 0.023 & 0.934 \\
\hline FSH $(\mathrm{IU} / \mathrm{L})$ & 0.665 & $0.004 *$ & -0.328 & 0.214 \\
\hline
\end{tabular}

$\mathrm{N}=$ Total Sample $\left(^{*}\right)=\mathrm{P}-$ value less than 0.05

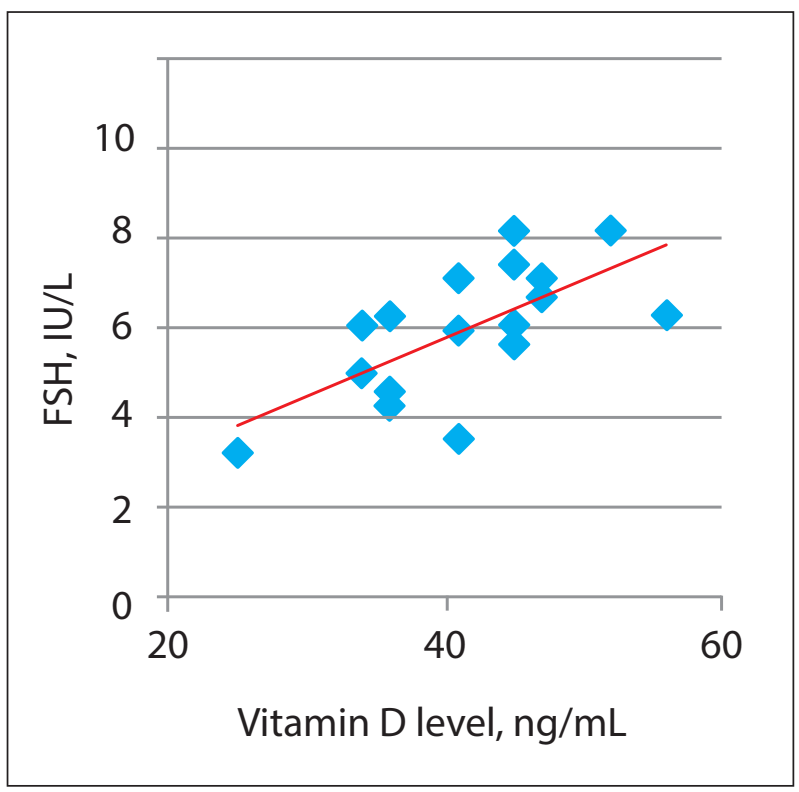

Figure 1 Positive correlation between Vit D and FSH levels in the control group.

trol group ( $p=0.004)$ (Figure 1), but the correlation was negative and non-significant in the PCOS group. Also, there were no relationships between the level of Vit $D$ and the other variables (age, weight, height, body mass index, LH) in both groups.

Sequencing of the VDR gene showed extensive polymorphisms in the PCOS patients and controls. Table $V$ presents the SNPs in the VDR gene, identified in both the PCOS and control groups and the genotype and allele frequencies for each SNP. No significant differences were seen between the two groups.

The study groups were assembled according to the genotypes of the different SNPs and the value of demographic and hormonal parameters, were obtained in each of the genotype. Table VI presents the value of only those parameters that showed significant difference in the different genotypes. As shown in Table VI, some of the variables were influenced by the genotype of a VDR SNP, while other showed no difference. Weight was significantly higher in females carrying GG genotype of rs2228570, AA genotype of rs11168266, AC genotype of rs3858733 and GG genotype of rs11168265, but BMI was higher only in the AC genotype of rs3858733. Among the hormonal parameters FSH was higher in the GG genotype of rs11168276 and LH in the GA genotype of rs121909790. Finally, Vit D levels were deficient in the GG genotype of rs11168276, CT genotype of rs731236 and GA genotype of rs11168265. 
Table V SNPs identified, their location, genotype and allele frequencies in the PCOS and control group and the comparison between the two groups.

\begin{tabular}{|c|c|c|c|c|c|c|c|}
\hline SNP(location) & Variation & Control & PCOS & OR & $\mathrm{Cl}$ & $x^{2}$ & $\mathrm{P}$-value \\
\hline \multirow{5}{*}{$\begin{array}{l}\text { rs } 1381425375 \\
\text { (prime UTR variant A/C) }\end{array}$} & TT & $16(94.12)$ & $16(100)$ & 1.00 & $0.019-53.45$ & nan & 1.000 \\
\hline & TG & $1(5.88)$ & - & 0.333 & $0.013-8.79$ & 0.97 & 0.324 \\
\hline & GG & - & - & 1.000 & $0.19-53.457$ & Nan & 1.000 \\
\hline & $\mathrm{T}$ & $33(97.0)$ & $32(100)$ & 2.91 & $0.114-74.076$ & 0.96 & 1.312 \\
\hline & G & $1(2.9)$ & & 0.344 & $0.013-8.745$ & 0.96 & 1.359 \\
\hline \multirow{5}{*}{$\begin{array}{l}\text { rs } 4307775 \\
\text { (Intron variant G/C) }\end{array}$} & CC & $2(11.76)$ & - & 0.181 & $0.008-4.268$ & 2.01 & 0.156 \\
\hline & CG & $6(35.29)$ & $6(37.50)$ & 5.000 & $0.199-125.785$ & 1.75 & 0.185 \\
\hline & GG & $9(52.94)$ & $10(62.50)$ & 5.526 & $0.234-130.343$ & 2.01 & 0.156 \\
\hline & $\mathrm{C}$ & $10(29.4)$ & $6(18.75)$ & 0.554 & $0.175-1.757$ & 1.02 & 0.312 \\
\hline & G & $24(70.5)$ & $26(81.25)$ & 1.806 & $0.569-5726$ & 1.02 & 0.312 \\
\hline \multirow{5}{*}{$\begin{array}{l}\text { rs } 4303288 \\
\text { (Intron variant A/C) }\end{array}$} & TT & $3(17.65)$ & $3(18.75)$ & 0.500 & $0.073-3.435$ & 0.50 & 0.477 \\
\hline & TG & $9(52.94)$ & $3(18.75)$ & 0.333 & $0.042-2.631$ & 1.12 & 0.288 \\
\hline & $\overline{G G}$ & $5(29.41)$ & $10(62.50)$ & 2.000 & $0.291-13.738$ & 0.50 & 0.477 \\
\hline & $\mathrm{T}$ & 15(44.1) & $9(28.1)$ & 0.496 & $0.178-1.382$ & 1.82 & 0.177 \\
\hline & G & 19(55.8) & $23(71.8)$ & 2.018 & $0.723-5.627$ & 1.82 & 0.177 \\
\hline \multirow{5}{*}{$\begin{array}{l}\text { rs111682935 } \\
\text { (prime UTR intron } \\
\text { variant G/A/T) }\end{array}$} & $\mathrm{CC}$ & $8(47.06)$ & $5(31.25)$ & 1.250 & $0.089-17.653$ & 0.03 & 0.868 \\
\hline & CA & 7 (41.18) & $10(62.50)$ & 2.286 & $0.522-10.011$ & 1.22 & 0.269 \\
\hline & AA & $2(11.76)$ & $1(6.25)$ & 0.800 & $0.057-11.298$ & 0.03 & 0.868 \\
\hline & $\mathrm{C}$ & $23(67.6)$ & $20(62.5)$ & 0.797 & $0.289-2.198$ & 0.19 & 0.660 \\
\hline & $\mathrm{A}$ & $11(32.3)$ & $12(37.5)$ & 1.255 & $0.455-3.459$ & 0.19 & 0.660 \\
\hline \multirow{5}{*}{$\begin{array}{l}\text { rs11168292 } \\
\text { (intron variant } C / A / G)\end{array}$} & GG & $8(47.06)$ & $5(31.25)$ & 1.250 & $0.089-17.653$ & 0.03 & 0.868 \\
\hline & GC & 7 (41.18) & $10(62.50)$ & 2.286 & $0.522-10.011$ & 1.22 & 0.269 \\
\hline & $\mathrm{CC}$ & $2(11.76)$ & $1(6.25)$ & 0.800 & $0.057-11.298$ & 0.03 & 0.868 \\
\hline & $G$ & $23(67.6)$ & $20(62.5)$ & 0.797 & $0.289-2.198$ & 0.19 & 0.660 \\
\hline & C & $11(32.3)$ & $12(37.5)$ & 1.255 & $0.455-3.459$ & 0.19 & 0.660 \\
\hline \multirow{5}{*}{$\begin{array}{l}\text { rs1173979145 } \\
\text { (prime UTR A/G) }\end{array}$} & TT & 16(94.12) & $16(100)$ & 1.000 & $0.019-53.457$ & NAN & 1.000 \\
\hline & TC & $1(5.88)$ & - & 0.333 & $0.013-8.793$ & 0.97 & 0.324 \\
\hline & $\mathrm{CC}$ & - & - & 1.000 & $0.019-53.457$ & NAN & 1.000 \\
\hline & $\mathrm{T}$ & $33(97.0)$ & $32(100)$ & 2.910 & $0.114-74.079$ & 0.96 & 1.359 \\
\hline & $\mathrm{C}$ & $1(2.9)$ & & 0.344 & $0.013-8.745$ & 0.96 & 1.359 \\
\hline \multirow{5}{*}{$\begin{array}{l}\text { rs11168276a } \\
\text { (intron C/T) }\end{array}$} & GG & 16(94.12) & $16(100)$ & 3.000 & $0.114-79.135$ & 0.97 & 0.324 \\
\hline & GA & - & - & 1.000 & $0.019-53.457$ & NAN & 1.000 \\
\hline & AA & $1(5.88)$ & - & 0.333 & $0.013-8.793$ & 0.97 & 0.324 \\
\hline & $G$ & $32(94.1)$ & $32(100)$ & 5.00 & $0.231-108.254$ & 1.94 & 0.600 \\
\hline & $A$ & $2(5.8)$ & & 0.200 & $0.009-4.330$ & 1.94 & 0.600 \\
\hline \multirow{5}{*}{$\begin{array}{l}\text { rs2228570b } \\
\text { (start lostmissense } \\
\text { variant } A / C / G / T)\end{array}$} & TT & $1(5.88)$ & $1(6.25)$ & 1.33 & $0.073-24.315$ & 0.04 & 0.845 \\
\hline & TC & $4(23.53)$ & $6(37.50)$ & 1.500 & $0.071-31.575$ & 0.07 & 0.793 \\
\hline & $\mathrm{CC}$ & 12(70.59) & $9(56.25)$ & 0.750 & $0.41-13.677$ & 0.04 & 0.845 \\
\hline & $\mathrm{T}$ & 6 & 8 & 1.556 & $0.473-5.117$ & 0.53 & 0.465 \\
\hline & $\mathrm{C}$ & 28 & 24 & 0.643 & $0.195-2.115$ & 0.53 & 0.465 \\
\hline \multirow{5}{*}{$\begin{array}{l}(\mathrm{rs} 121909790 \mathrm{c} \\
\text { missense variant } \mathrm{C} / \mathrm{G} / \mathrm{T})\end{array}$} & GG & $17(100)$ & 15(93.75) & 0.886 & $0.017-47.358$ & Nan & 1.000 \\
\hline & GA & - & $1(6.25)$ & 3.387 & $0.128-89.369$ & 1.08 & 0.844 \\
\hline & AA & - & - & 1.129 & $0.021-60.369$ & 1.10 & 0.295 \\
\hline & G & $34(100)$ & $31(96.8)$ & 0.304 & $0.012-7.747$ & 1.08 & 0.844 \\
\hline & A & & $1(3.1)$ & 3.286 & $0.129-83.633$ & 1.08 & 0.844 \\
\hline
\end{tabular}




\begin{tabular}{|c|c|c|c|c|c|c|c|}
\hline \multirow{5}{*}{$\begin{array}{l}\text { (rs10783218 } \\
\text { splice region variantintron } \\
\text { variant3 prime UTR } \\
\text { variant G/A) }\end{array}$} & CC & $12(70.59)$ & 15(93.75) & 1.240 & $0.023-67.036$ & Nan & 1.000 \\
\hline & CT & $5(29.41)$ & $1(6.25)$ & 0.160 & $0.016-1.560$ & 2.97 & 0.084 \\
\hline & TT & - & - & 0.806 & $0.015-43.598$ & Nan & 1.000 \\
\hline & $\mathrm{C}$ & $29(85.2)$ & $31(96.8)$ & 5.345 & $0.589-48.524$ & 2.68 & 0.200 \\
\hline & T & $5(14.7)$ & 1(3.1) & 0.187 & $0.021-1.699$ & 2.68 & 0.200 \\
\hline \multirow{5}{*}{$\begin{array}{l}\text { (rs11168267 } \\
\text { intron variant } \mathrm{G} / \mathrm{A} / \mathrm{C})\end{array}$} & CC & $14(82.35)$ & $11(68.75)$ & 0.786 & $0.044-14.026$ & 0.03 & 0.869 \\
\hline & CT & $2(11.76)$ & $4(25)$ & 2.545 & $0.391-16.550$ & 1.00 & 0.318 \\
\hline & TT & $1(5.88)$ & $1(6.25)$ & 1.273 & $0.071-22.720$ & 0.03 & 0.869 \\
\hline & $\mathrm{C}$ & 30 & 26 & 0.578 & $0.147-2.273$ & 0.63 & 0.505 \\
\hline & $\mathrm{T}$ & 4 & 6 & 1.731 & $0.440-6.810$ & 0.63 & 0.505 \\
\hline \multirow{5}{*}{$\begin{array}{l}\text { (rs11168266d } \\
\text { intron variant } C / T \text { ) }\end{array}$} & GG & - & $1(6.25)$ & 2.739 & $0.100-74.872$ & 0.87 & 0.350 \\
\hline & GA & $7(41.18)$ & $4(25)$ & 0.200 & $0.007-6.037$ & 1.53 & 0.216 \\
\hline & $\mathrm{AA}$ & 10 & $11(68.75)$ & 0.365 & $0.013-9.979$ & 0.87 & 0.350 \\
\hline & G & $7(2.05)$ & $6(18.75)$ & 0.890 & $0.264-3.003$ & 0.04 & 0.851 \\
\hline & A & $27(79)$ & $26(81.2)$ & 1.123 & $0.333-3.791$ & 0.04 & 0.851 \\
\hline \multirow{5}{*}{$\begin{array}{l}\text { (rs11168265e } \\
\text { intron variantdownstream } \\
\text { gene variant } C / T \text { ) }\end{array}$} & GG & $5(29.41)$ & $5(31.25)$ & 1.667 & $0.251-11.071$ & 0.28 & 0.595 \\
\hline & GA & $7(41.18)$ & $8(50)$ & 1.143 & $0.230-5.670$ & 0.03 & 0.03 \\
\hline & AA & $5(29.41)$ & $3(18.75)$ & 0.600 & $0.090-3.986$ & 0.28 & 0.595 \\
\hline & $\mathrm{G}$ & 17 & 18 & 1.286 & $0.488-3.390$ & 0.26 & 0.611 \\
\hline & A & 17 & 14 & 0.778 & $0.295-2.051$ & 0.26 & 0.611 \\
\hline \multirow[t]{5}{*}{ (rs7975232 C/A) } & GG & $2(11.76)$ & $1(6.25)$ & 0.438 & $0.032-5.926$ & 0.40 & 0.610 \\
\hline & GT & $8(47.06)$ & $7(43.75)$ & 1.750 & $0.129-23.703$ & 0.18 & 0.671 \\
\hline & TT & $7(41.18)$ & $8(50)$ & 2.286 & $0.169-30.959$ & 0.40 & 0.527 \\
\hline & $\mathrm{G}$ & 12 & 9 & 0.717 & $0.253-2.036$ & 0.39 & 0.532 \\
\hline & $T$ & 22 & 23 & 1.394 & $0.491-3.957$ & 0.39 & 0.532 \\
\hline \multirow{5}{*}{$\begin{array}{l}\text { (rs731236f } \\
\text { synonymous variantA/G) }\end{array}$} & TT & $6(35.29)$ & $4(25)$ & 0.667 & $0.102-4.354$ & 0.18 & 0.671 \\
\hline & TC & $7(41.18)$ & $8(50)$ & 1.714 & $0.339-8.676$ & 0.43 & 0.513 \\
\hline & $\mathrm{CC}$ & $4(23.53)$ & $4(25)$ & 1.500 & $0.230-9.796$ & 0.18 & 0.671 \\
\hline & $\mathrm{T}$ & 19 & 16 & 0.789 & $0.300-2.080$ & 0.23 & 0.632 \\
\hline & $\mathrm{C}$ & 15 & 16 & 1.267 & $0.481-3.337$ & 0.23 & 0.632 \\
\hline \multirow{5}{*}{$\begin{array}{l}\text { (rs3858733g } \\
\text { prime UTR variant } \mathrm{T} / \mathrm{G} \text { ) }\end{array}$} & $\overline{\mathrm{AA}}$ & $13(76.47)$ & $13(81.25)$ & 1.000 & $0.018-54.155$ & Nan & 1.000 \\
\hline & $\mathrm{CA}$ & $4(23.53)$ & $3(18.75)$ & 0.750 & $0.139-4.035$ & 0.11 & 0.737 \\
\hline & CC & - & - & 1.000 & $0.018-54.100$ & Nan & 1.000 \\
\hline & A & $30(88.2)$ & $29(90.6)$ & 1.289 & $0.265-6.267$ & 0.10 & 1.000 \\
\hline & C & $4(11.7)$ & $3(9.37)$ & 0.776 & $0.160-3.773$ & 0.10 & 1.000 \\
\hline \multirow{5}{*}{$\begin{array}{l}\text { (rs97293 prime } \\
\text { UTR variant } \mathrm{G} / \mathrm{C} / \mathrm{T} \text { ) }\end{array}$} & $\overline{A A}$ & $8(47.06)$ & $8(50.00)$ & 2.000 & $0.150-26.734$ & 0.28 & 0.595 \\
\hline & CA & $7(41.18)$ & $7(43.75)$ & 1.000 & $0.238-4.198$ & 0.00 & 1.000 \\
\hline & CC & $2(11.76)$ & $1(6.25)$ & 0.0500 & $0.037-6.683$ & 0.287 & 0.595 \\
\hline & C & 11 & 9 & 0.818 & $0.285-2.347$ & 0.14 & 0.708 \\
\hline & A & 23 & 23 & 1.222 & $0.426-3.505$ & 0.14 & 0.708 \\
\hline \multirow{5}{*}{$\begin{array}{l}\text { (rs28535633 } \\
\text { prime UTR variant } C / T \text { ) }\end{array}$} & GG & $12(70.59)$ & $13(81.25)$ & 1.080 & $0.020-58.6555$ & Nan & 1.000 \\
\hline & GA & $5(29.41)$ & $3(18.75)$ & 0.554 & $0.108-2.833$ & 0.51 & 0.475 \\
\hline & $\overline{A A}$ & - & - & 0.926 & $0.017-50.287$ & Nan & 1.000 \\
\hline & $\mathrm{G}$ & $29(85.2)$ & $29(90.6)$ & 1.667 & $0.364-7.629$ & 0.44 & 0.709 \\
\hline & A & $5(14.7)$ & $3(9.37)$ & 0.600 & $0.131-2.746$ & 0.44 & 0.709 \\
\hline
\end{tabular}

Note: The superscripts $\left({ }^{a}, b, c, d, e, f, g\right)$ on the SNPs number, points to the SNPs that show significant differences in biochemical or hormonal parameters in different genotypes, as presented in Table VI. 
Table VI Effect of the SNP genotype in VDR on the studied variables in the study group.

\begin{tabular}{|c|c|c|c|c|c|}
\hline SNP & Variable & Wild-type & Heterozygous & Vatiant & $\mathrm{P}$-value \\
\hline \multirow{3}{*}{ rs11168276a } & SNP genotyping & GG & GA & $\mathrm{AA}$ & \\
\hline & Vitamin $D(\mathrm{ng} / \mathrm{mL})$ & $42.6 \pm 6.4$ & - & $25.0 \pm 0.0$ & $\begin{array}{l}G G \text { vs } A A \\
P=0.018\end{array}$ \\
\hline & FSH (IU/L) & $6.0 \pm 1.3$ & - & 3.20 .0 & $\begin{array}{l}G G \text { vs } A A \\
p=0.049\end{array}$ \\
\hline \multirow[b]{2}{*}{ rs2228570b } & SNP genotyping & TT & $\mathrm{TC}$ & $\mathrm{CC}$ & \\
\hline & Weight (kg) & $85.0 \pm 0.0$ & $61.5 \pm 12.8$ & $55.7 \pm 9.6$ & $\begin{array}{l}\text { TT vs CC } \\
\mathrm{P}=0.046\end{array}$ \\
\hline \multirow[b]{2}{*}{ rs11168266d } & SNP genotyping & GG & GA & $\mathrm{AA}$ & \\
\hline & Weight (kg) & - & $51.7 \pm 7.3$ & $63.7 \pm 12.6$ & $\begin{array}{l}\text { AA vs AG } \\
P=0.039\end{array}$ \\
\hline \multirow{3}{*}{ rs3858733g } & SNP genotyping & $\mathrm{AA}$ & $A C$ & $\mathrm{CC}$ & \\
\hline & Weight (kg) & $55.6 \pm 9.2$ & $69.0 \pm 16.1$ & - & $\begin{array}{l}A C \text { vs AA } \\
p=0.049\end{array}$ \\
\hline & BMI $\left(\mathrm{kg} / \mathrm{m}^{2}\right)$ & $32.5 \pm 7.7$ & $42.9 \pm 9.9$ & - & $\begin{array}{l}A C \text { vs } A A \\
p=0.042\end{array}$ \\
\hline \multirow[b]{2}{*}{ rs121909790c } & SNP genotyping & GG & GA & AA & \\
\hline & LH (IU/L) & $15.6 \pm 1.9$ & $47.0 \pm 0.0$ & - & $\begin{array}{l}\text { GG vs GA } \\
P=0.012\end{array}$ \\
\hline \multirow{3}{*}{ rs11168265e } & SNP genotyping & GG & GA & AA & \\
\hline & Weight (kg) & $77.7 \pm 10.3$ & $73.2 \pm 10.3$ & $58.2 \pm 3.7$ & $\begin{array}{l}G G \text { vs } A A \\
p=0.043\end{array}$ \\
\hline & Vitamin $D(\mathrm{ng} / \mathrm{mL})$ & $45.0 \pm 2.4$ & $44.8 \pm 6.6$ & $57.3 \pm 2.3$ & $\begin{array}{l}\text { AA vs AG } \\
P=0.008\end{array}$ \\
\hline \multirow[b]{2}{*}{ rs731236f } & SNP genotyping & TT & $\mathrm{CT}$ & $\mathrm{CC}$ & \\
\hline & VitaminD $(\mathrm{ng} / \mathrm{mL})$ & $46.0 \pm 1.2$ & $44.0 \pm 6.7$ & $54.8 \pm 5.5$ & $\begin{array}{l}C C \text { vs } C T \\
P=0.024\end{array}$ \\
\hline
\end{tabular}

Note: The superscripts $\left({ }^{a}, b, c, d, e, f, g, h\right)$ on the SNPs link these SNPs to the SNPs in the Table V.

\section{Discussion}

Our interest developed in this study on patients with PCOS, since it is shown in many investigations that Vit D and VDR play several essential roles in the female reproductive organs. The VDR spreads over most of the female reproductive tissues and are involved in uterus development during preparation for the process of embryo implantation $(28,29)$. In addition, the VDR are also present on the ovaries and are involved in the formation of vesicles process (folliculogenesis) and the synthesis of sex hormones (steroidogenesis of sex hormones) (6). However, our results in Saudis compared with or contrasted several of the findings reporting Vit D deficiency in PCOS.

In our study, the females suffering from PCOS were 16 in number and matched in age and BMI with the control group (17 in number). Vit D levels were higher in the PCOS, compared to the control group and the difference was significant statistically. The optimal level according to the "Reference Ranges« as set by the Mayo Medical Laboratories (30) is 25-80 $\mathrm{ng} / \mathrm{mL}$ In our study all the females suffering from PCOS had optimal Vit D levels and amongst the normal controls only $1 / 17(5.8 \%)$ had sub-optimal Vit D levels, indicating that in Saudis Vit D deficiency is not involved in the pathogenesis of PCOS. These results are in line with those reported by Wehr and colleagues on Austrian population (10).

When the hormone levels were compared, the level of LH was significantly higher in the PCOS compared to the controls, while the FSH levels did not differ significantly. However the LH/FSH ratio was significantly higher in the PCOS compared to the controls. These results are in agreement with the results of Polson et al. (31), Taylor et al. (32) and Daghestani et al. (33), but disagree with the results of Norman et al. (34) and Adams et al. (35). Other studies have also reported that PCOS is characterized by high levels of $\mathrm{LH}$ due to low levels of estrogen and progesterone resulting from lack of ovulation process (36). In addition, this may be due to the high sensitivity of the pitu- 
itary gland to gonadotropin-releasing hormone $(\mathrm{GnRH})$, as pointed out by Hayes et al. (37).

Interestingly, when Vit D level was correlated with all the studied parameters, a positive correlation was identified between the level of Vit D and FSH in the control group only. In the PCOS patients Vit D correlated negatively with $\mathrm{FSH}$, but the correlation was not statistically significant (38). In an earlier study Zolkova et al. (39) had shown that there was an improvement in FSH level with specific doses of Vit D. However, a recent report failed to show any correlation between $\mathrm{Vit} \mathrm{D}$ and $\mathrm{FSH}$ and $\mathrm{LH}$ in young females (40).

The present study also failed to show any association between Vit. D and BMI, though earlier investigations showed that Vit D associates with BMI (10, $11,13)$. Recently, Duhil de Benaze (40) also failed to show any association between $\mathrm{Vit} D$ and $\mathrm{BMI}$.

In the present study, the unique feature was that we conducted a comprehensive survey of the VDR gene by sequencing all exons and part of the introns on both sides of the exon. Our genotyping results showed that there were no significant associations of any of SNPs in VDR gene with PCOs in Saudi women. These results are in line with the results reported by Wehr et al. (21) who did not find any association between 8 polymorphisms in VDR gene and PCOS. In our study the frequency of genotypes and alleles of several of the SNPs were very different when the PCOS patients were compared with the controls, but the statistical significance was not achieved. This is probably due to the smaller number of sample size used in this study.

Interestingly, literature review revealed that there are remarkable population variations in the association between Vit D deficiency and genetic variants of VDR. Mahmoudi et al. (12) showed significant association of rs7975232 (GT) in VDR with severity of the disease in Iranian population, while no such association was found in Egyptians, despite significantly lower Vit D levels in PCOS (41). In Silesian women endogenous $V$ it $D$ deficiency and VDR polymorphisms were not associated with »classic «PCOS phenotype (42), though, in the South Indian females the VDR gene polymorphism was shown as a remarkable inheritable risk factor for PCOS (43).

Many of the SNPs identified in our study have not been reported in any of the previous studies. Hence, studies on larger study groups are required to confirm association if any between the SNP and PCOS development.

Furthermore, in our study we also found that some of the genotypes affected the levels of the anthropometric and hormonal parameters. The variant rs731236 (CC) associated with the level of Vit D in the PCOs group, but not with LH level. This result is contrary to studies conducted by Ranjzad et al. (25) and Bagheri et al. (23) who showed association between $\mathrm{Vit} D$ and the level of $\mathrm{LH}$. We also identified several relationships between variables of the study and SNP genotypes which were not mentioned in previous studies on VDR and PCOS. These results show that the inter-individual variations may be a result of variations in the genotype of VDR. Further detailed studies are warranted to provide a clearer picture of the associations.

The major limitation of this study was the small sample size. However, as a pilot study it provided several interesting facts, which need confirmation by further more detailed studies. Secondly, during this study, the level of insulin was not measured. So we could not provide evidence to validate a number of studies that associate $V$ it $D$ with insulin resistance. Also, the level of Vit D and its association with insulin resistance in type II diabetes could not be confirmed $(13,21)$. Further studies on a larger sample size are required to confirm these results.

\section{Conclusion}

This study shows that in Saudis Vit D deficiency does not contribute to PCOS development and comparing the results with those in the literature highlight the wide variations that exist in the prevalence of $\mathrm{Vit}$ $D$ deficiency in PCOS in different populations. During this study, extensive polymorphisms are revealed in the VDR gene on sequencing. Though no significant differences are observed in the frequency of these variants in the Saudi PCOS and normal population, but several variants influence the demographic and hormonal parameter levels in the studied population. Since extensive population differences exist and studies on VDR variants are few, it is suggested that further detailed studies are conducted to obtain a clearer picture of the association between VDR gene polymorphisms and PCOS etiology.

Acknowledgements. The authors extend their appreciation to the National Plan for Science, Technology and Innovation (MAARIFAH), King Abdul-Aziz City for Science and Technology, Kingdom of Saudi Arabia, grant Number No 08-MED 604-2. We thank all the subjects for their cooperation and participation in the study. We would also like to thank all the participants (researchers, technicians and nurses) for their notable contribution.

Funding. This Work was funded by the National Plan for Science, Technology and Innovation (MAAR(FAH), King Abdul-Aziz City for Science and Technology, Kingdom of Saudi Arabia, grant Number No 08-MED 604-2.

\section{Conflict of interest statement}

The authors stated that they have no conflicts of interest regarding the publication of this article. 


\section{References}

1. Uitterlinden, AG, Fang, $Y$, van Meurs JB, van Leeuwen $H$, Pols HA. Vitamin D receptor gene polymorphisms in relation to Vitamin D related disease states. The Journal of Steroid Biochemistry and Molecular Biology 2004; 89, 187-93.

2. Mahmoudi T. Genetic variation in the vitamin D receptor and polycystic ovary syndrome risk. Fertility and Sterility 2009; 92: 1381-3.

3. Darwish $H$, and DeLuca HF. Vitamin D-regulated gene expression. CRC Crit Rev Eukaryotic Gene Expression 1993; 3: 89-116.

4. Agic A, Xu H, Altgassen C, Noack F, Wolfler MM, Diedrich K, Friedrich M, Taylor RN, Hornung D. Relative expression of 1,25-dihydroxyvitamin D3 receptor, vitamin D 1ahydroxylase, vitamin D 24-hydroxylase, and vitamin D 25-hydroxylase in endometriosis and gynecologic cancers. Reproductive Sciences 2007; 14: 486-97.

5. Lerchbaum E, Obermayer-Pietsch B. Mechanisms in endocrinology: Vitamin D and fertility: a systematic review. European Journal of Endocrinology 2012; 166(5), 765-78.

6. Parikh G, Varadinova M, Suwandhi P, Araki T, Rosenwaks Z, Poretsky L Seto-Young D. Vitamin D regulates steroidogenesis and insulin-like growth factor binding protein1 (IGFBP-1) production in human ovarian cells. Hormone and Metabolic Research 2010; 42 754-7.

7. Collinson P. Laboratory medicine is faced with the evolution of medical practice. J Med Biochem 2017; 36: 2115.

8. Hahn $S$, van Halteren WB, Roesler $S$, Schmidt $M$, Kimmig R, Tan S, Mann K, Janssen OE. The combination of increased ovarian Volume and follicle number is associated with more severe hyperandrogenism in German women with polycystic ovary syndrome. Experiments in Clinical Endocrinology and Diabetes 2006; 114: 175-81.

9. Ngo DT, Chan WP, Rajendran S, Heresztyn T, Amarasekera A, Sverdlov AL, O'Loughlin PD, Morris HA, Chirkov YY, Norman RJ, Horowitz JD. Determinants of insulin responsiveness in young women: impact of polycystic ovarian syndrome, nitric oxide, and vitamin D. Nitric Oxide 2011; 25: 326-30.

10. Wehr E, Pilz S, Schweighofer N, Giuliani A, Kopera D, Pieber TR, Obermayer-Pietsch B. Association of hypovitaminosis $D$ with metabolic disturbances in polycystic ovary syndrome. European Journal of Endocrinology 2009; 161(4): 575-82.

11. Yildizhan R, Kurdoglu M, Adali E, Kolusari A, Yildizhan B, Sahin HG, Kamaci M. Serum 25-hydroxyvitamin D concentrations in obese and non-obese women with polycystic ovary syndrome. Archives of Gynecology and Obstetrics 2009; 280(4): 559-63.

12. Mahmoudi T, Gourabi H, Ashrafi M, Yazdi RS, Ezabadi Z. Calciotropic hormones, insulin resistance, and the polycystic ovary syndrome. Fertility and Sterility 2010; 93: 1208-14.

13. Li HW, Brereton RE, Anderson RA, Wallace AM, Ho CK. Vitamin D deficiency is common and associated with metabolic risk factors in patients with polycystic ovarysyndrome. Metabolism 2011; 60: 1475-81.
14. Perovic Blagojevic I, Eror T, Pelivanovic J, Jelic S, KoturStevuljevic J, Ignjatovic S. Women with polycystic ovary syndrome and risk of cardiovascular disease. J Med Biochem 2017; 36: 259-69.

15. Bikle, D. D. Vitamin D metabolism and function in the skin. Molecular and Cellular Endocrinology 2011; 347(1): 80-9.

16. Kinuta K, Tanaka H, Moriwake T, Aya K, Kato S, Seino Y.; Vitamin $D$ is an important factor in estrogen biosynthesis of both female and male gonads. Endocrinology 2000; 141: 1317-24.

17. Holick MF.; Vitamin D deficiency. New England Journal of Medicine 2007; 357: 266-81.

18. Koshiyama H, Sone T, Nakao K. Vitamin-D-receptorgene polymorphism and bone loss. Lancet 1995; 345: 990-1.

19. Dusso AS, Brown AJ, Slatopolsky E. Vitamin D. Am J Physiol Renal Physiol 2005; 289(1): F8-28.

20. Morrison NA, Qi JC, Tokita A, Kelly PJ, Crofts L, Nguyen TV, Sambrook PN, Eisman JA. Prediction of bone density from vitamin D receptor alleles. Nature 1994; 367: 284-7.

21. Wehr E, Trummer O, Giuliani A, Gruber HJ, Pieber TR, Obermayer-Pietsch B. Vitamin D-associated polymorphisms are related to insulin resistance and vitamin $D$ deficiency in polycystic ovary syndrome. European Journal of Endocrinology 2011; 164: 741-9.

22. Mahmoudi T, Majidzadeh-A K, Farahani $H$, Mirakhorli $M$, Dabiri R, Nobakht H, Asadi A. Association of vitamin D receptor gene variants with polycystic ovary syndrome: $A$ case control study. Int J Reprod Biomed (Yazd) 2015; 13(12): 793-800.

23. Mcgrath JJ, Saha S, Burne TH, Eyles, D W. A systematic review of the association between common single nucleotide polymorphisms and 25-hydroxyvitamin D concentrations. The Journal of Steroid Biochemistry and Molecular Biology 2010; 121(1): 471-7.

24. Bagheri M, Rad IA, Jazani NH, Nanbakhsh F. Lack of Association of Vitamin D Receptor Fokl (rs10735810) $(\mathrm{C} / \mathrm{T})$ and Bsml (rs1544410) (A/G) Genetic Variations with Polycystic Ovary Syndrome Risk: a Case-control Study from Iranian Azeri Turkish Women. Maedica (Buchar) 2012; 7(4): 303-8.

25. Ranjzad F, Mahban A, Shemirani Al, Mahmoudi T, Vahedi M, Nikzamir A, Zali MR. Influence of gene variants related to calcium homeostasis on biochemical parameters of women with polycystic ovary syndrome. Journal of Assisted Reproduction and Genetics 2011; 28: 225-32.

26. Bagheri M, Abdi Rad I, Hosseini Jazani N, Nanbakhsh F. Vitamin D Receptor Taql Gene Variant in Exon 9 and Polycystic Ovary Syndrome Risk. Int J Fertil Steril 2013; 7(2):116-21. Epub 2013 Jul 31.

27. The Rotterdam ESHRE/ASRM sponsored PCOS consensus workshop group. Revised 2003 consensus on diagnostic criteria and long term health risks related to polycystic ovary syndrome (PCOS). Human Reproduction, 
Volume 19, Issue 1, 1 January 2004, Pages 41-47, https://doi.org/10.1093/humrep/deh098

28. Bagot CN, Troy PJ, Taylor HS. Alteration of maternal Hoxa10 expression by in vivo gene transfection affects implantation. Gene Therapy 2000; 7: 1378-84.

29. Du H, Daftary GS, Lalwani SI, Taylor HS. Direct regulation of HOXA10 by 1,25-(OH)2D3 in human myelomonocytic cells and human endometrial stromal cells. Molecular Endocrinology 2005; 19: 2222-33.

30. Kennel KA, Drake MT, Hurley DL. Vitamin D deficiency in adults: when to test and how to treat. Mayo Clin Proc 2010 Aug; 85(8): 752-7; quiz 757-8. doi:10.4065/mcp.2010.0138.

31. Polson DW, Wadsworth J, Adams J, Franks S. Polycystic ovaries-a common finding in normal women. The Lancet 1988; 331(8590): 870-2.

32. Taylor AE, McCourt B, Martin KA, Anderson EJ, Adams JM, Schoenfeld D, Hall JE. Determinants of abnormal gonadotropin secretion in clinically defined women with polycystic ovary syndrome. Journal of Clinical Endocrinology \& Metabolism 1997); 82(7): 2248-56.

33. Daghestani M, Daghestani M, El-Mazny A. The Correlation between Anthropometric Measurements, Insulin and Reproductive Hormones in Saudi Females with and without Polycystic Ovary Syndrome. Medical Journal of Cairo University 2008; 76(2): 385-92.

34. Norman RJ, Shamin M, Masters S. Ethnic differences in insulin and glucose response to glucose between white and Indian women with polycystic ovary syndrome. Fertility and Sterility 1995; 63(1): 58-62.

35. Adams JM, Taylor AE, Crowley WF, \& Hall JE. Polycystic ovarian morphology with regular ovulatory cycles: insights into the pathophysiology of polycystic ovarian syndrome. Journal of Clinical Endocrinology \& Metabolism 2004; 89(9): 4343-50.

36. Marshall JC, Eagleson CA. Neuroendocrine aspects of polycystic ovary syndrome. Endocrinology and Metabolism Clinics of North America, 1999; 28: 295-324.

37. Hayes FJ, Seminara SB, Crowley WF Jr. Hypogonadotropic hypogonadism. Endocrinol Metab Clin North Am 1998 Dec; 27(4): 739-63, vii. Review.
38. Waldstreicher J, Santoro NF, Hall JE, Filicori M, Crowley WF Jr. Hyperfunction of the hypothalamic-pituitary axis in women with polycystic ovarian disease: indirect evidence for partial gonadotroph desensitization. J Clin Endocrinol Metab 1988; 66(1): 165-72.

39. Žofková I, Scholz G, Starka L. Effect of calcitonin and 1, $25(\mathrm{OH})$ 2-vitamin D3 on the FSH, $\mathrm{LH}$ and testosterone secretion at rest and LHRH stimulated secretion. Hormone and Metabolic Research 1989; 21(12): 682-5.

40. Duhil de Bénazé G, Brauner R, Souberbielle JC. There is no association between vitamin $D$ status and characteristics of central precocious puberty in girls. Eur J Pediatr 2017 Dec; 176(12): 1677-80. doi: 10.1007/s00431017-3022-9. Epub 2017 Sep 29.

41. El-Shal AS, Shalaby SM, Aly NM, Rashad NM, Abdelaziz AM. Genetic variation in the vitamin D receptor gene and vitamin $D$ serum levels in Egyptian women with polycystic ovary syndrome. Mol Biol Rep 2013 Nov; 40(11): 6063-73. PubMed PMID: 24078159.

42. Jedrzejuk $D$, Łaczmański $Ł$, Milewicz A, KuliczkowskaPłaksej J, Lenarcik-Kabza A, Hirnle L, Zaleska-Dorobisz $U$, Lwow F. Classic PCOS phenotype is not associated with deficiency of endogenous vitamin $D$ and VDR gene polymorphisms rs731236(Taql), rs7975232 (Apal), rs1544410 (Bsml), rs10735810 (Fokl): a case-control study of lower Silesian women. Gynecol Endocrinol 2015; 31(12): 976-9. doi:10.3109/09513590.2015. 1062865. Epub 2015 Sep 30. PubMed PMID: 26422783.

43. Siddamalla S, Reddy TV, Govatati S, Erram N, Deenadayal $M$, Shivaji S, Bhanoori $M$. Vitamin D receptor gene polymorphisms and risk of polycystic ovary syndrome in South Indian women. Gynecol Endocrinol 2017 Sep 3: 1-5. doi:10.1080/09513590.2017. 1371128. [Epub ahead of print] PubMed PMID: 28868946.

44. Han FF, Lv YL, Gong LL, Liu H, Wan ZR, Liu LH. VDR Gene variation and insulin resistance related diseases. Lipids Health Dis 2017 Aug 19; 16(1): 157-169 doi: 10.1186/s12944-017-0477-7. PubMed PMID: 28822353; PubMed Central PMCID: PMC5563043. 